\title{
THE PROBLEM WITH TAX TREATIES
}

\author{
African countries have been brainwashed into thinking that they need \\ [tax] treaties. But they don't.
}

- Tax treaty negotiator, African country

Stories of tax-dodging corporate giants make headlines on a weekly basis. Nonetheless, governments manage to collect over US $\$ 2$ trillion in corporate income tax each year, much of it from big multinational businesses. ${ }^{1}$ This book is about the rules governments have negotiated to divide the tax base among themselves: how they are designed to work, rather than how they are circumvented by unscrupulous companies and individuals. ${ }^{2}$ As a long tradition of legal scholarship argues, those rules, written by a club of higher-income countries, deny lowerincome countries a fair share. ${ }^{3}$ Tax is hardly unique in this regard, and the past two decades have seen backlashes against institutions of global economic governance that exhibit such a bias, including the IMF, the World Trade Organization (WTO), and the network of bilateral investment treaties (BITs). ${ }^{4}$ There are now some signs of organized discontent in the international tax regime, but its longstanding resilience, while other lopsided regimes have faltered, makes it an interesting case in the broader story of global economic governance.

The key mechanism depriving lower-income countries of tax revenues is something they have signed up for - and in which they continue to participate-entirely voluntarily: a network of bilateral treaties, and the international standards that those treaties encode into hard law. Tax treaties cover 82 percent of the world's foreign direct investment (FDI) stocks, including 81 percent of the FDI in lowerincome countries. ${ }^{5}$ They set limits on when, and in some cases at what rate, signatories can tax cross-border economic activity, primarily imposing restrictions on the host countries of FDI. Many legal scholars are skeptical of the benefits. According to Tsilly Dagan, the main effect of these tax treaties is "regressive 
redistribution - to the benefit of the developed countries at the expense of the developing ones." Kim Brooks and Richard Krever agree that "the success of the high-income states in negotiating ever more treaties has come at the expense of the tax revenue bases of low-income countries." If this is the case, why have lowerincome countries been willing to sign more than a thousand of these treaties?

The vast majority of literature-policy and academic — sees tax treaties as instruments through which lower-income countries compete for inward investment. A cross-country study of the reasons countries sign tax treaties, conducted by Fabian Barthel and Eric Neumayer in 2012, found that countries were more likely to sign up when their competitors for foreign investment had already done so. ${ }^{8}$ This conclusion appears to be borne out in policy discourse too. For example, investment promotion literature from countries including Kenya and Zimbabwe highlights tax treaties as important factors that should attract investors. ${ }^{9}$ In budget speeches introducing tax treaties to Uganda's parliament, successive finance ministers have explained that their purpose was "to protect taxpayers against double taxation, and to ensure that the tax system does not discourage direct foreign investment" and "to reduce tax impediments to cross border trade and investment." 10 A study conducted by the Ministry of Finance of Peru states that "these conventions create a favourable environment for investment. In signing a double taxation convention, a country is sending a positive signal to foreign investment and offering investors security with respect to the elements negotiated." 11

There are a number of problems with this: there is little evidence that tax treaties have a positive impact on investment in lower-income countries; I found conflicting views among those involved in the treaty-making process in lowerincome countries as to the purpose of tax treaties, with many of those who negotiate treaties skeptical that they attract investment; capital-exporting countries are frequently the ones initiating and driving negotiations, not lower-income countries; and the tax competition literature does not tell us why lower-income countries typically give away far more in negotiations than they need to in order to secure an agreement.

To the extent that tax competition is a fact, then, it is a social fact. What matters is how it is understood by different actors. In this book, I characterize two competing narratives among those involved in making tax treaties. A tax competition motivation, based on the unsubstantiated claim that treaties will attract investment, is shared among those who are less familiar with the technical details. This includes politicians, nonspecialist civil servants, and business executives who lobby them. Treaties are seen as a trade-off between investment promotion and revenue raising, although the fiscal costs, which are hard to estimate, are not always given much weight in the assessment. 
The narrative among tax treaty specialists, both in government and in business, is different. Often socialized into a transnational policy community, their detailed technical knowledge comes as part of a package, developed and refined among experts from OECD countries. A powerful logic of appropriateness pervades this community: the OECD's model tax treaty is the acceptable way to tax multinational companies. Its bias against lower-income countries was never agreed to by those countries at a political level; instead, it is justified in technical terms as more economically efficient. Proponents of this view accept that companies' investment decisions may well be influenced by the presence or absence of a particular treaty, and a country with a wide treaty network may be expected to have more cross-border investment. The main mechanism through which this should occur, they suggest, is the convergence on OECD standards set out in the treaty, not the creation of tax-rate-based distortions. Tax professionals in advisory firms and multinational companies share with civil servants the objective of disseminating OECD standards. If they want to be part of this expert community, there is little room for those from lower-income countries to challenge such a long-standing consensus, even where it exhibits a strong bias against them.

For half a century, higher-income countries have taken advantage of these two narratives, together with capacity constraints and imperfect rationality in lowerincome countries, to negotiate hundreds of treaties that constrain the taxing rights of lower-income countries unnecessarily. All along, but rarely acknowledged, the higher-income countries have been in competition with each other to give their multinational investors a competitive edge by securing the most advantageous tax treaties. Yet the tax costs of this competition endure for a long time in the lowerincome countries with which they sign. Almost three hundred African tax treaties, well over half those in force, are more than two decades old, meaning that they were signed in the last century.

The closest analogy to this situation is BITs. Like tax treaties, they are countryspecific tax incentives with questionable effectiveness at promoting investment, which have nonetheless proliferated throughout the Global South. Literature on BITs recognizes that to understand lower-income countries' decisions to conclude, we must acknowledge that policymakers' rationality is "bounded." 12 BITs, it is argued, were at first perceived by lower-income countries as a cost-free means to signal political and economic ties with others, and to attract investment. Little attention was paid to the potential downsides. It was only years after they were signed that investors began to use their dispute settlement clauses, and even then lower-income countries did not immediately learn from each other's experiences, although they did become much more reluctant to sign them. ${ }^{13}$

Tax treaties are a more difficult case to explain than BITs, because their costs to signatory governments are immediate, predictable, and significant. There has 
been no slowdown in tax treaty negotiation, as there has been for BITs, but some lower-income countries have begun to question the costs and benefits of their tax treaty networks. Indonesia, Senegal, South Africa, Rwanda, Argentina, Mongolia, Zambia, and Malawi are among those that have canceled or renegotiated tax treaties, while others, such as Uganda, have undertaken reviews. ${ }^{14}$ Civil society groups have begun to mount campaigns against particular tax treaties, culminating in TJNA's lawsuit in Kenya. ${ }^{15}$ Even the IMF now cautions lower-income countries that they "would be well-advised to sign treaties only with considerable caution." 16

Aside from questioning the existence of treaties per se, there is a steady drumbeat of concern that the tax treaty system has too great a bias toward the interests of capital-exporting "residence" countries and against capital-importing "source" countries. According to a press release by a group of finance ministers from francophone lower-income countries, "The global tax system is stacked in favour of paying taxes in the headquarters countries of transnational companies, rather than in the countries where raw materials are produced. International tax and investment treaties need to be revised to give preference to paying tax in 'source' countries." 17 The African Tax Administration Forum (ATAF), a membership organization for revenue authorities, notes that "Africa is still beset by serious issues such as ... tax treaties with no appropriate tax allocation rights between source and residence taxation and thus susceptible to abuse." ${ }^{18}$ An official statement from the Indian government concurs: "The OECD principles have evolved from the perspective of only higher-income countries since they were prepared by the OECD countries, and many issues relating to lower-income countries have not been taken into consideration. This has resulted in serious curtailment of the taxing powers of the lower-income countries in relation to international transactions." 19

Bilateral tax treaties differ from BITs in that they are drafted in a highly multilateralized context. Each one is derived directly or indirectly from a model formulated and promoted by the OECD, which inherited this role from the League of Nations. That model, naturally, embodies the interests of OECD countries, a club of capital-rich higher-income nations. Alternatives exist, in particular the UN model bilateral treaty, which makes some modest changes to the OECD model in the interests of lower-income countries. Yet it is the OECD model that predominates, even in tax treaties signed by pairs of lower-income countries. ${ }^{20}$ Put simply, lower-income countries have given up large chunks of their tax bases by signing these treaties, with few certain gains to show as a result. This book is an attempt to understand why.

It is a substantively important question affecting the livelihoods of hundreds of millions of people. Today, on average, OECD member states collect taxes amounting to 34 percent of gross domestic product (GDP), while in Africa the 
equivalent figure is half that amount. ${ }^{21}$ This reflects a lower level of taxable capacity within their economies, and the availability of "rent" income from natural resource extraction and overseas aid. ${ }^{22}$ On the other hand, corporate tax revenue is twice as important to African governments as it is to OECD governments as a share of total revenue raised, and tends to come disproportionately from multinational investors. ${ }^{23}$ Lower-income countries' decisions over the taxation of inward investment are thus crucially important to the provision of public services and ultimately to their development prospects.

\section{What Are Tax Treaties?}

The global network of over three thousand bilateral tax treaties is the "hard law" foundation of the international tax regime: its DNA. Enforceable in domestic courts and-increasingly - through a bespoke system of international arbitration, tax treaties take precedence over domestic law in most countries. ${ }^{24}$ This foundational role has two quite different elements. On the one hand, tax treaties are explicitly political, each one the outcome of a bilateral negotiation between two countries that carves up the right to tax the cross-border economic activity between them. The language of "taxing rights" commonly used in discussions about tax treaties reflects the sacrifice of sovereignty that they entail, ${ }^{25}$ and goes some way to explaining why states have only been willing to enter into binding agreements at the bilateral level, where they have more control over the content. ${ }^{26}$

On the other hand, most of that content is a cookie-cutter replication of one of the multilateral models, largely deriving from the OECD model. ${ }^{27}$ Just as DNA is organized into chromosomes, all tax treaties follow the same structure of articles, and the most significant variation within many of those articles comes down to just a few words. Nonetheless, the invariant text also constrains countries' taxing rights and is the product of a century of multilateral negotiations. Furthermore, beyond the treaty text itself, the models also incorporate detailed commentaries and associated standards that courts will use when interpreting treaty articles based on them. Thus, the statement that tax treaties are the regime's hard-law foundation also means that they convert a corpus of multilateral soft law into binding, enforceable hard law.

The formal function of tax treaties, reflected in the more commonly used term "double taxation agreement" (DTA) and the formal titles of most treaties, is to promote trade and investment by reducing the potential that companies operating in the two countries will be taxed twice on the same income. For example, the introduction to the model tax treaty developed by the United Nations Committee of Experts on International Cooperation in Tax Matters ("the UN model"), which 
is intended as a template for lower-income countries to use in negotiations, states: "Broadly, the general objectives of bilateral tax treaties therefore include the protection of taxpayers against double taxation with a view to improving the flow of international trade and investment and the transfer of technology." 28 Similarly, the introduction to the OECD Model Tax Convention on Income and on Capital ("the OECD model") describes its main purpose as "to clarify, standardise, and confirm the fiscal situation of taxpayers who are engaged in commercial, industrial, financial, or any other activities in other countries through the application by all countries of common solutions to identical cases of double taxation." 29

When a taxpayer has a potential tax liability in more than one state, the taxpayer will face double taxation if each state claims the right to tax it. States can leave double taxation intact, but this may create an onerous burden on taxpayers that deters cross-border trade and investment. As Tsilly Dagan shows, capitalexporting states have a greater incentive to relieve double taxation unilaterally, but they prefer a more coordinated approach. This is because, as well as more comprehensively resolving the problem; cooperation transfers some of the cost of double taxation relief from the capital-exporting state to the capital-importing state. Both the political and technical roles played by tax treaties are achieved primarily by limiting taxation in capital-importing states: the bilateral negotiation affects how much of the fiscal cost will be borne by the host state, but so does the adoption of supposedly technocratic concepts and standards embedded in the model treaties.

Table 1.1 summarizes some of the main restrictions on taxing rights that tax treaties impose. As can be seen, a large proportion of the treaty is designed to restrict the host country's taxing rights over foreign investors. Broadly speaking, it does this in three ways. First, it sets activity thresholds for a foreign company's activity in the host country, although the length of time, extent of presence, and type of activity that form these thresholds can vary. Below these thresholds the host country cannot tax a foreign company or individual at all, and the treaty therefore shifts the balance of taxing rights away from the host country by an amount that depends on the specific threshold. For example, Mongolia's tax treaty with China, signed in 1991, prevents it from taxing Chinese companies' construction sites within its borders (of which there are many) unless they are present for eighteen months. In practice this exempts many Chinese construction projects from Mongolian tax.

Second, in some instances tax treaties allocate the right to tax in a binary way. Income such as royalties, pensions, and many types of capital gains may be taxable only by the home country once the treaty comes into force, again shifting the balance of taxing rights in its favor. For example, where a company in the host country pays out pensions to its former employees who now reside in the treaty 
TABLE 1.1. Selected provisions of tax treaties and their effects

\begin{tabular}{lll}
\hline ARTICLE & $\begin{array}{l}\text { TAX(ES) } \\
\text { CONCERNED }\end{array}$ & EFFECT \\
\hline 5 & $\begin{array}{l}\text { Corporate } \\
\text { income tax }\end{array}$ & $\begin{array}{l}\text { Permanent establishment. Prescribes that states can tax a } \\
\text { foreign company only if its activity within their borders meets } \\
\text { the thresholds set out under the treaty definition of "permanent } \\
\text { establishment" (PE). Typically these thresholds include a } \\
\text { minimum amount of physical presence over a minimum length } \\
\text { of time, and a list of business activities that do or do not } \\
\text { count as a PE. }\end{array}$
\end{tabular}

7

10-12 Withholding taxes

Corporate income tax

Capital gains tax

Others

All

All
Business profits. Sets out how the profits made by a foreign business should be calculated for the purpose of taxation by the state in which it is operating. The state can only take into account profits that it is permitted to by this article, and it must allow the taxable profits to be reduced by any expenses specified in this article.

Withholding tax limits. In addition to profit taxes, states often levy taxes on overseas payments made by companies, such as interest payments, royalties, and dividends. These clauses specify the types of payments on which a country can levy withholding taxes, and the maximum rates at which they can be levied. The maximum rates are usually set lower than the statutory rates in the capital-importing country, as a key concession making the treaty advantageous to the capitalexporting country.

Capital gains tax. The country in which a foreign investor realizes a capital gain can tax it only in the circumstances set out in this clause. This may include that a shareholding being sold must constitute a minimum threshold (so that the host country can tax gains only on direct investment and not on portfolio investment).

Other forms of taxation. Generally this states that only the home country has the right to levy taxes on its residents that are not explicitly mentioned in the treaty.

Relief of double taxation. All previous articles limit the capital importer's taxing rights. This article is the quid pro quo, under which the capital exporter agrees either that its resident taxpayers will receive credits against their tax bills for equivalent taxes paid in the treaty partner or that it will exempt income and capital in the treaty partner from taxation altogether.

Mutual agreement procedure. Where the provisions of the treaty are interpreted differently such that a taxpayer still incurs double taxation, this provides for a mechanism through which the countries can try to resolve the dispute. Some treaties signed since the mid-2000s include taxpayer-initiated binding arbitration within this clause.

Exchange of information. Obliges and provides a legal authority for states to cooperate with each other when investigating taxpayers with affairs in both countries. 
partner (typically former expatriate employees of a multinational firm who have worked for a subsidiary in the host country), many treaties prohibit the host country from taxing those payments. ${ }^{30}$ In Uganda, a dispute between the tax authority and telecommunications multinational Zain relates to the UgandaNetherlands tax treaty, which prevents Uganda from levying capital gains tax on certain types of gains made by Dutch residents, including the sale of holding companies. $^{31}$

Third, in some instances tax treaties set a maximum tax rate on cross-border transactions that the host state must not exceed. Lower-income countries commonly levy withholding taxes on dividends, interest payments, royalties, and service fees, and the maximum rates imposed by tax treaties are probably their most visible and high-profile aspects. For example, the Philippines imposes taxes of up to 30 percent on dividend payments abroad and 20 percent on interest payments, but some of its tax treaties have the effect of reducing these rates to 5 percent and 0 percent, respectively. According to analysis by Petr Janský and Marek Šedivý, these reductions cost the Philippines-the biggest loser from a sample of fourteen lower-income countries-revenue amounting to US\$509 million $\left(0.17 \%\right.$ of GDP) in $2015 .^{32}$

In return for these restrictions on taxation in the host country, the signatories also agree to bear the cost of eliminating any remaining double taxation incurred by their own residents, where they are the home country, by making allowances for taxes paid in the treaty partner when calculating their tax liability. This is usually done through a combination of credits for tax paid abroad and exempting income earned in the treaty partner altogether. From the 1970s to the 1990s, it was common to include a "tax-sparing" clause, in which the home country agreed to honor any tax incentives its firms were granted by the treaty partner, by giving them credits as if they had paid taxes in full. This practice, which created costs for capital-exporting countries, fell out of fashion with the publication of an OECD report, Tax Sparing: A Reconsideration, which argues that these provisions were vulnerable to tax avoidance, and encouraged investors to repatriate profits rather than invest them in the lower-income country. ${ }^{33}$

If the flows of investment and people between the two treaty partners are broadly equal, changes to the balance of taxing rights resulting from the treaty may affect the incentives for taxpayers to move or invest between the signatories. They will not, however, have a significant impact on the overall distribution of taxing rights between the two countries. This is because each country is simultaneously a home and host country with respect to different investors, and so will gain and lose in roughly equal proportion from the restrictions on host or home country taxing rights. But when a treaty is concluded between two countries whose capital stocks are not equal, the settlement will have distributional consequences. 
The same applies at the system level: a country with a broadly balanced capital account may face a net fiscal loss from one treaty but gain from others; where a country is overwhelmingly a capital importer-as lower-income countries are, almost by definition-the sum total of imbalances across its treaties can be considerable.

The negotiated content of the treaty may be more or less advantageous to the capital-exporting country depending on the level of the permanent establishment (PE) threshold, the allocation of the binary provisions, and the maximum withholding tax rates set. But it is normally the case that even treaties that are comparatively favorable to the capital-importing country still place significant restrictions on their taxing rights relative to domestic legislation. For example, for Uganda, accepting the concept of PE, regardless of how broadly it is defined, is a restriction relative to a domestic tax framework that does not include the concept. ${ }^{34}$ This illustrates the power of the model treaties, drafted over decades by tax experts from higher-income countries, which have these concepts baked in. It also illustrates that the real impact of tax treaties is often not to alleviate double taxation but to transfer some of the cost of doing so from the capitalexporting country to the capital importer, or to reduce the overall effective tax rate of investors operating across the two countries.

\section{The First Puzzle: Why Sign at All?}

Tax treaties can be expensive for lower-income countries, costing them significant amounts of tax revenue. Sebastian Beer and Jan Loeprick of the IMF estimate that each additional tax treaty concluded by an African country is associated with a 5 percent reduction in its corporate tax revenues. ${ }^{35}$ If governments' policy preferences are "rational," these costs should be justified in some way by the likely benefits, either in terms of aggregate national welfare or in terms of more parochial benefits for the individuals who determine those preferences. The strong version of this book's underlying contention is that such a rational justification rarely exists, making most decisions to conclude a tax treaty puzzling.

A hypothetical rational policymaker would have little trouble finding work in the policy and academic law literature that might give them pause for thought. For forty years, legal scholarship has debated the extent to which the sacrifice of taxing rights by a lower-income country in signing a tax treaty is justified by its impact on the tax treatment of inward investment. ${ }^{36}$ Critical legal scholars have argued that tax treaties place too much of the burden of relieving double taxation on lower-income countries, or that the entire rationale is "a myth" or "aid 
in reverse-from poor to rich countries," because, rather than relieving double taxation, tax treaties between higher-income and lower-income countries merely shift the burden of doing so from the former to the latter. ${ }^{37}$ This is because the credit or exemption provisions in treaties that limit the home country's right to tax its own residents- the quid pro quo for the restrictions in the host countryare largely unnecessary. Most major capital-exporting countries relieve double taxation incurred by their investors, either by giving credits against their tax bill for tax paid abroad or increasingly by exempting foreign profits from tax altogether. ${ }^{38}$ Indeed, Tsilly Dagan demonstrates using game theory that, absent a treaty, the Pareto optimal outcome for a home country will always be to take unilateral steps to relieve double taxation incurred by its multinationals that invest abroad. ${ }^{39}$ For capital-importing lower-income countries, then, the best strategy should be to sit tight.

Authors who believe that tax treaties can nonetheless attract investment in lower-income countries make the following points. ${ }^{40}$ First, not all capitalexporting countries relieve double taxation unilaterally in all circumstances, and so there may be a strong argument for a tax treaty in these cases. Second, although in other instances there may not be what Dagan refers to as "heroic" double taxation, there would still remain instances in which companies are caught out, because each country's tax code defines a particular transaction differently. Treaties help resolve this both by standardizing many definitions and by providing taxpayers with an avenue through which to initiate dispute settlement between the treaty partners. Third, an important benefit to businesses from tax treaties is that they create stability. A tax treaty is effectively a tool to deliver a credible commitment that many aspects of the tax treatment of an investment will not change in a way that is dramatically worse for the investor-for example, a large hike in withholding taxes.

Finally, it is also argued that tax treaties create a more favorable treatment for investors because they reduce taxes that are a direct cost to businesses. This occurs if income is already exempt from tax in the home country or if the home tax rate is lower than the host tax rate on the income concerned. In simple terms, if both countries tax corporate profits at the same rate, a business will be indifferent to which country is granted the taxing rights in the tax treaty, since it will pay the same in either case. But if the home country does not tax profits earned overseas, or its tax rate is much lower than that of the host country, then investors stand to benefit significantly from a treaty that ensures they are taxed only in their home state. This makes investments in the host country a more attractive proposition. It is one reason why investment is often channeled through hub jurisdictions, which combine low effective tax rates with wide networks of treaties 
that allocate them-rather than to host countries- to the lion's share of taxing rights. ${ }^{41}$

Eduardo Baistrocchi adds that Dagan's result does not hold when multiple lower-income countries are competing for inward investment. In this situation they are in a prisoner's dilemma, and once one host country has signed a tax treaty with a given capital exporter, the optimal solution for the others is to follow suit. ${ }^{42}$ This competition model also applies if tax treaties are reducing direct costs to investors, as opposed to eliminating double taxation-here tax treaties may be tools of tax competition in the same manner as statutory tax rates, in which case lower-income countries face a collective action problem.

Perhaps more pertinent is the empirical question: Do tax treaties increase investment in lower-income countries? Unfortunately, the economic evidence is not much clearer cut. For every published study that finds a positive association between tax treaties and investment in lower-income countries, there is another that does not. When a comprehensive collection of studies was published in 2009, some even found a negative association. ${ }^{43}$ Since then, some studies using aggregate investment statistics have found a positive impact from tax treaties in lowerincome countries, ${ }^{44}$ while others have found none. ${ }^{45}$ The quality and coverage of such data are notoriously poor in the case of lower-income countries, and there are considerable methodological challenges. In particular, it is difficult to distinguish between new investment resulting from a treaty and investment diverted or routed from elsewhere to take advantage of its terms.

Two promising avenues are company-level microdata in place of aggregate investment data, and network analysis techniques. Papers using data on the foreign affiliates of Swedish, German, US, and Austrian multinationals have all found positive effects in certain circumstances. ${ }^{46}$ Unfortunately, coverage of lowerincome countries is still patchy, such that only the Swedish study has sufficient coverage of sub-Saharan countries to be able to apply its results to that region: the effect it found was also small. ${ }^{47} \mathrm{~A}$ second innovation is network analysis, which allows researchers to control for treaty shopping. Several studies using this technique appear to point in a more positive direction. ${ }^{48}$ It is too soon, however, to make any conclusive statements about if, when, and how tax treaties might affect investment in lower-income countries.

A final note about the evidence base concerns tax-sparing clauses, which are added to some tax treaties signed by lower-income countries to give a stronger effect to tax incentives granted by the lower-income country to multinationals from the home country. The OECD asserts that "investment decisions taken by international investors resident in credit countries are rarely dependent on or even influenced by the existence or absence of tax sparing provisions in treaties." 49 In spite of this, several studies have found positive and significant effects of tax- 
sparing provisions on investment in lower-income countries, independent of the presence of a tax treaty per se. ${ }^{50}$

What would a policymaker in a lower-income country, seeking to rationally analyze all the evidence available, conclude? Certainly, the sweeping statements about the benefits of tax treaties to lower-income countries often seen in policy literature seem hard to sustain. In all probability, any effect of a tax treaty on investment depends on the characteristics of the two signatories' tax systems, on the presence or absence of specific clauses, on whether the treaty contains effective protection against treaty shopping, and on the treaties concluded by a country's competitors. The research question lower-income countries need answered, then, is not "Do tax treaties attract investment?" but "In what circumstances might a tax treaty attract investment, and on what terms?" Yet such qualifications are absent from policy discourse and, as the evidence in this book will show, from policymakers' descriptions of their own considerations. It thus seems unlikely that the prevalent view, that tax treaties have a blanket investment-promoting effect that outweighs the cost of foregone revenue, is based on a rational assessment of the strength of the available economic or legal evidence.

\section{The Second Puzzle: Why Sign Away So Much?}

Even if we do not accept the strong contention that the benefits of any tax treaty are unlikely to exceed the costs, a puzzle still remains: those costs are frequently much greater than they need to be. Within the parameters set by the model treaties, there is considerable variation in tax treaties' content, which may affect their impact on investment flows and on tax revenues. Even if we accept that tax treaties have some investment-promoting effect, data showing the way in which they have been negotiated by lower-income countries demonstrate the systematic sacrifice of far more taxing rights than would have been necessary to reach agreement, creating revenue losses that surely tip the cost-benefit calculation into the red. It is hard to conceptualize this as a rational pattern of negotiations.

The UN model treaty is generally regarded as a better compromise between the costs and benefits for lower-income countries than the OECD model treaty, ${ }^{51}$ although, as Oladiwura Ayeyemi Eyitayo-Oyesode argues, it is "only a modest improvement on the OECD rules." 52 Where the two models vary, it is almost always because the UN model allocates greater taxing rights to the capitalimporting country. But some research has demonstrated that the outcome of tax treaty negotiations between higher-income and lower-income countries are generally closer to the OECD model than to the UN model. Where UN model 
clauses differ significantly from those of the OECD model, in areas such as the PE definition and capital gains tax, they often appear in only a minority of treaties signed by lower-income countries. ${ }^{53}$ The UN model clauses are found relatively more frequently in treaties between two non-OECD countries than in treaties signed by one OECD country and one non-OECD country. This suggests that lower-income countries seek, but fail to secure, more expansive taxing rights in negotiations with OECD countries, where the division of taxing rights really matters.

A few papers have looked for patterns within the negotiated content of tax treaties. Kim Brooks observes that Australia has tended to be more generous in the terms of its tax treaties with lower-income countries than Canada, and that the latter has become less generous over time. ${ }^{54}$ Charles Irish suggests that the prevalence of African tax treaties with Nordic countries and West Germany in the 1970s was a result of these countries' openness to negotiate and to conclude treaties on preferential terms. These countries "do recognise the necessity of greater taxation at source and are willing to enter into tax agreements favourable to developing countries." ${ }^{55}$ Veronika Dauer and Richard Krever find marked differences between countries in Africa and Asia, noting that "as a group, these African countries appear not to have been as successful as Asian countries in retaining taxing rights." ${ }^{\text {6 }}$ Jinyan Li finds that China has changed its preference in negotiations, from preferring clauses that expanded its taxing rights as a capital importer to preferring clauses that expand its taxing rights as a capital exporter. ${ }^{57}$ Eduardo Baistrocchi adds that China was initially willing to accept treaties on OECD members' terms, despite the costs it incurred as a capitalimporting country, in order to signal that it was open to investment. ${ }^{58}$

Do these patterns imply rational negotiation strategies? One question in particular is how the stock of FDI between countries shapes the content of treaties. Broadly speaking, we would expect countries to defend their source taxing rights much more when they are overwhelmingly in the position of capital importer, since the costs of a one-sided treaty will be higher. As Honey Lynn Goldberg suggests, "Treaty partners having unequal income flows will allocate jurisdiction to tax so as to achieve a more even balance between the two extremes." ${ }^{59}$ Three studies have considered the asymmetry in the FDI relationship between the two negotiating countries and the withholding rates in those treaties. ${ }^{60}$ Each found that, as Goldberg predicted, withholding tax rates are higher where the asymmetry in the FDI relationship between treaty partners is higher, shielding countries that are overwhelmingly capital importers from some revenue losses. Looking at the content of tax treaties as a whole, rather than only withholding taxes, I found the precise opposite. Treaties tend to impose greater restrictions on lower-income countries' source taxing rights when the distribution of FDI between signatories 
is more one-sided, suggesting that, when lower-income countries need investment more, they are more willing to give taxing rights away ${ }^{61}$ This is consistent with descriptive studies finding that, when negotiating with higher-income countries, lower-income countries are quite unsuccessful at obtaining the versions of clauses that they seem to prefer when negotiating treaties with each other. ${ }^{62}$ Clearly, FDI asymmetry may point to a power asymmetry in negotiations, but there is more to the variation than that. For example, I also found that lower-income countries secure a greater share of the taxing rights as they gain experience in negotiating and applying treaties.

\section{Beyond Domestic Politics ...}

Most international relations literature on global tax governance, in common with that on economics, assumes that signing tax treaties is a rational course of action for lower-income countries, and concerns itself little with the terms on which they do so. In general, it accepts the double taxation problem as fact in modeling the negotiation of tax treaties, assuming that states' first order of preference is to resolve this problem, while their second-order preference is to maximize their share of the tax base. ${ }^{63}$ Some studies modify this by focusing on competition between capital-importing states, which may alter their preferences, creating a more intense preference for signing a treaty despite the loss of the tax base that it entails. ${ }^{64}$ All of this literature struggles once we question the rationality of concluding tax treaties on the terms that lower-income countries have done. Perhaps we need to look more closely at what motivates the political leaders who ultimately sign tax treaties. After all, "the state is not an actor but a representative institution constantly subject to capture and recapture, construction and reconstruction by coalitions of social actors." ${ }^{\prime 65}$

Consider the classic model in which democratic political leaders' economic policy preferences are shaped by the aggregation of two constituencies' preferences: voters, who are affected through general welfare effects and want the provision of public goods, and interest groups such as businesses and trade unions, which seek private benefits for their members and can influence policy through campaign contributions. ${ }^{66}$ This model is unhelpful for tax treaties, because it is hard to ascertain any effect in either direction, especially given the manifest lack of any strong pressure from either voters or interest groups.

Pressure from voters could in principle go either way. A prevailing public belief that tax treaties will attract inward investment may encourage governments in democracies, especially those of the left, to seek to conclude them in order to create jobs. ${ }^{67}$ There is no evidence that political partisanship affects a government's 
enthusiasm for tax treaties in this way, or that democracies are more likely to conclude them. While other tax instruments provide politicians with opportunities for credit claiming, regardless of their effectiveness, ${ }^{68}$ no such possibilities are provided by an instrument that few voters are aware of. Indeed, a median voter effect may push a government in the opposite direction, because tax treaties reduce the tax liabilities of foreign multinationals, compromise the government's ability to redistribute wealth and provide public services, and undermine efforts to force foreign multinationals to pay their "fair share" of tax.

There is a similar ambiguity with respect to domestic interest groups. Capitalists and other wealthy individuals in a lower-income country's elite may benefit from the opportunities for "round tripping," a form of tax avoidance, created by some treaties. ${ }^{69}$ A good example of this is India's treaty with Mauritius, which for many years was abused by Indian nationals who routed their domestic investments via Mauritius to make use of an exemption from Indian capital gains tax that was intended for foreign investors, not Indian residents. ${ }^{70}$ Catherine Ngina Mutava points to instances of "political-motivated" treaties driven by diplomatic rather than economic motivations. ${ }^{71}$ Although such concerns have clearly been a part of some tax treaty dynamics, the bulk of discussion about tax treaties in lowerincome countries is focused on the benefits they may provide to foreign multinational companies rather than any selective benefits they may offer elites. It is also hard to see such advantages in the majority of tax treaties, which are with highertax countries rather than tax havens.

In practice, elites may have more reasons to oppose the conclusion of tax treaties. For domestic businesses, a tax treaty is in effect a reduction in the tax burden facing their foreign-owned competitors, placing the domestic firms at a competitive disadvantage. Those evading tax may also be concerned about the revenue authority gaining information on any wealth they have deposited in the treaty partner, through the information exchange provisions of tax treaties. Some studies have even found a negative impact of tax treaties on investment flows, which they attribute to this dynamic. ${ }^{72}$ With a few exceptions, however, the jurisdictions that act as tax-friendly investment conduits for multinational firms are not the same as those that act as havens for illicit wealth, so any conflict between direct investment promotion and offshore evasion may again be limited to a small number of treaties. ${ }^{73}$

The exception to this story is lobbying on behalf of multinational firms, which clearly stand to gain from tax treaties. The interviews and archival research in this book suggest that lobbying is largely a phenomenon of the Global North, and most effective when directed not toward politicians but toward specialist bureaucrats. In contrast, multinationals' local affiliates in lower-income countries direct 
requests via their embassies to their home governments, not directly to host governments.

There is, in sum, little evidence for organized interest group pressure for the conclusion of tax treaties in lower-income countries, just as there is almost no political or public debate about them in democracies. It is therefore just as likely that political actors may block the ratification of tax treaties, as we will see in chapter 6 . When the negotiators interviewed for this research commented on their country's politicians, it was indeed predominantly along the lines that they had slowed down the ratification process.

\section{... Beyond Bureaucratic Capacity}

It was an admission of past mistakes by a civil servant that originally motivated this research project. While I was researching tax planning by a multinational company in Ghana, a tax policy official told me that his country had lost out in tax treaty negotiations through poor preparation and had not fully taken into account the way treaties could allow certain jurisdictions to act as conduits for tax avoidance. ${ }^{74}$

Empirical legal research often highlights deficits in the knowledge, capacity, and ideas of those making the decisions. As early as 1974, Charles Irish, reflecting on his experience in Zambia, bemoaned lower-income countries' "unawareness of the adverse nature of double taxation agreements" and "unquestioned acceptance of the status quo." ${ }^{75}$ Lower-income countries, he wrote, "have or believe they have a relatively weak bargaining position," while higher-income countries "have a propensity to take advantage" of them. ${ }^{76}$ Tsilly Dagan suggested that the tax treaties myth concealed "much more cynical goals, particularly redistributing tax revenues from the poorer to the richer signatory countries." ${ }^{\prime 7}$

Doubts about the quality of lower-income countries' tax treaty policymaking are expressed in even more forthright terms by lawyers from those countries themselves. Festus Aukunobera, the author of a chapter on Uganda in a volume on different countries' approaches to treaty negotiation, argues that "tax administration and tax policy officials in Uganda are not sufficiently trained in the area of tax treaties and international taxation. As a result, Uganda has a weak tax treaty negotiation team that concludes treaties more intensively reflecting the position of the other contracting state. ${ }^{\prime 78}$ His Colombian counterpart, Natalia Quinoneswho subsequently became a negotiator for her country—describes in her chapter how a decision by the Uribe government in 2004 to adopt a policy of "attracting investment at any price" led to poorly prepared negotiations that resulted in an 
outcome that was less favorable to Colombia than might otherwise have resulted. ${ }^{79}$ In a study based on interviews with negotiators from seven African countries, Catherine Ngina Mutava observed that few had clear negotiation policies in place, and as a result they were "slowly ceding their taxing rights over income earned within their jurisdiction." 80

An important clarification is needed up front, as I introduce these observations about the level of understanding and preparation among negotiators from lower-income countries. It is not hard to find intelligent, astute, and well-informed negotiators from lower-income countries, whose meticulousness and tenacity are acknowledged by their opposite numbers. What is at issue here is the structural constraints in which they operate: a relative lack of experience and training combined with bureaucratic and political pressures that reduce their room to maneuver. ATAF, a body representing revenue authorities, emphasizes that "Africa is still faced with, among others, inadequate resources and level of expertise in international tax policy as well as clashes with other political priorities like inequality, climate change, unemployment and security that constrain their ability to influence decision-making on global tax issues." ${ }^{\prime 1}$

In general terms, we expect that bureaucratic capacity and the quality of state institutions have a strong bearing on the capacity to raise revenue, especially where domestic interest groups and global capital markets exert a downward pressure. ${ }^{82}$ As the case studies in this book illustrate, it is certainly the case that a weaker, less specialized tax bureaucracy is not as able to provide evidence-based advice to its political leaders, leaving them more exposed to the influence of ideas, interest groups, and foreign governments. The creation of a stronger, specialist international tax unit within the bureaucracy can lead to a more focused, critical approach to the exogenous pressures to make tax treaties. It may also endogenize those pressures, creating an institutional logic of tax treaty making, not least through a group of civil servants with a vested interest in maintaining an active tax treaty negotiation program.

This is not, however, a question of bureaucratic capacity per se but something more idiosyncratic. Tax treaty policy is a small, specialist function, a niche within a niche. Negotiations are frequently led by just one individual, or at most by a handful of staff, operating in obscurity with little scrutiny. Much therefore depends on the knowledge and experience of this individual or group of people, as well as quite specific resourcing decisions concerning the number of people in such a team. Comparing the UK with the United States, for example, or Cambodia with Vietnam illustrates that the size and competence of the tax treaty negotiating team does not necessarily correlate with the size and capability of the state apparatus, even that pertaining to taxation. For this reason, the focus of this book 
is precisely on the knowledge and experience of a handful of officials, as well as on how they are constrained within a system of checks and balances.

\section{The Argument}

International tax is not unfairly seen as complex and obscure. A partner at a law firm once described it to me as a specialism that other tax lawyers and accountants, already the pointiest headed in their professions, consider arcane and nerdy. ${ }^{83}$ Because of this obscurity, many participants in policy debates must necessarily act without a comprehensive understanding of the available information, especially those in capacity-constrained contexts, which are more likely to be found in lower-income countries. This gives considerable power to actors whose authoritative command of technical knowledge is recognized, allowing them to shape others' preferences. We must therefore analyze the actions of those involved in tax treaty making through a framework of bounded rationality, the notion that policymakers rely on cognitive shortcuts to filter the available information. ${ }^{84}$

\section{Political (Nonspecialist) Actors}

The role of tax treaties is constructed differently by different actors, along two axes: Global North to Global South, and dependent on a person's level of technical knowledge. For this reason, chapters 3 and 4 discuss nonspecialist and tax specialist actors separately. Consider first the former group, including most civil servants, politicians, and business executives. Here, the tax treaties myth prevails: treaties are black boxes that stimulate investment flows across borders by resolving a generalized problem of double taxation-or more simply still, by lowering the effective tax rate on cross-border investment. In this view, tax treaties act rather like a geographically specific tax incentive, a tool of tax competition. ${ }^{85}$ It should be noted that these pressures are largely indirect and anticipated, as tax treaties are simply too low salience among voters or special interest groups to become deeply politicized.

Looked at along a North-South axis, tax competition works both ways. From the perspective of the government of capital-importing country $\mathrm{A}$, the absence of a treaty with capital-exporting country $\mathrm{X}$ will disadvantage it in competing for investment, especially if its competitors B and C have tax treaties with $\mathrm{X}$. This is the framing that underpins studies of tax treaty dissemination found in international relations literature. ${ }^{86}$ The government of X, however, may also be concerned that its outward-investing multinationals are disadvantaged when 
competing in country A, compared with their competitors from $\mathrm{Y}$ and $\mathrm{Z}$, countries that already have treaties with A. The ideas that drive tax competition, which may differ from legal and economic facts, act in both directions: while we commonly focus on competition for inward investment, countries also compete for outward investment opportunities.

\section{The International Tax Community}

Let us now turn to the transnational community of tax treaty negotiators and administrators, tax lawyers and advisers, and those working on cross-border taxation within multinational firms. In this book I use the concept of "transnational policy community," which consists of public and private officials with shared educational or professional backgrounds, mutual affinity, and widely accepted principles and which operates as a club. ${ }^{87}$ Because the international tax community has always bridged the public and private sectors, this framing is more appropriate than the widely used concept of an "epistemic community" of private individuals that acts as an exogenous influence on government bureaucracies. ${ }^{88}$

Members of the international tax community are endowed with considerable specialist technical knowledge that is ordered within socially constructed frames and embodied in the OECD model tax treaty, which codifies its members' view of the right way of doing international tax. The project of concluding more and more bilateral tax treaties is primarily a means of protecting multinational companies from taxation that might occur in the wrong way-that is, in ways that deviate from OECD standards. Such standardization is partially consistent with the emphasis on double taxation in tax treaty discourse, since that is one potential consequence of inconsistent tax rules among countries. But it is only one, alongside others such as excessive, complex, unpredictable, and economically inefficient taxation, and more recently "double nontaxation," when inconsistent rules and inadequate cooperation permit tax avoidance and evasion.

Convergence with OECD standards is not mutually exclusive with a logic of tax competition, since the bilateral character of the tax treaty regime means that multinational firms operating between countries with a treaty are likely to gain selective benefits from these protections. But it is not the same as the tax treaties myth. Indeed, many members of the international tax community on both sides of the North-South divide see tax treaties as a means of reducing the costs for investors after they have decided to invest, not as a means to encourage them to invest in the first place. Such motivations may be guided less by a logic of consequences whereby the fiscal costs to the lower-income country are justified by the investment gains, and more by a logic of appropriateness, wherein it would be undesirable for an investor to face difficulties because of the lack of a treaty. 
Civil servants who have learned specialist technical knowledge about tax treaties as they join the international tax community also hold different ideas than other actors at a national level who do not have the same specialist training. As they understand the technical detail of tax treaties better, officials become increasingly aware of their costs, and of the limited evidence that they will attract inward investment. Often, they become more persuasive critics of the status quo that disadvantages their country, and stronger negotiators as a result. But as they learn how the international tax community conceptualizes tax treaties, many also come to regard tax treaties' true role as lying outside any immediate increase in investment. They move from a logic of consequences to one of appropriateness, and their preferences for treaty partners and treaty content shift. The nature and extent of officials' learning can therefore shape the extent to which they support or oppose particular treaties.

\section{Business Power and the Politics of Knowledge}

The technical and nontechnical mechanisms do not exist in isolation from each other; they interact at a national level. Scholarship examining the national political economy of international tax rules is limited to only a few examples, ${ }^{89}$ and the prevailing, state-centric view considers national preferences to be a function of the aggregate welfare implications and interest group politics concerned with the tax-driven effects of investment promotion and revenue raising. ${ }^{90}$ Because transnational corporate capital has a clear interest in reduced taxation, and there is no organized lobby against it, states are expected to have a first-order preference for stimulating trade and investment by concluding tax treaties that eliminate double taxation, and a second-order one for sacrificing as little tax revenue as possible when doing so. ${ }^{91}$ Because this framing entails a number of assumptions that are hard to sustain, at least for lower-income countries, I consider political actors' analysis of their own incentives to be filtered through the heuristic of the tax treaties myth.

In contrast, members of a transnational policy community take for granted certain focal points, which may lead them to different preferences in the domestic context than those of political actors, even if they share the same end goals. If community members have sufficient instrumental power, the national preferences arrived at by governments may differ from those that might be arrived at simply through analyzing the presumed interests of domestic stakeholder groups, even once we take into account the heuristics used by political actors. My analysis of control over the process of making treaties focuses on veto points. ${ }^{92}$ This power may result from formal bureaucratic and political responsibilities, but technical specialists may also hold a de facto veto created by the complex technical content 
and obscure terminology associated with tax treaties, which forces nonspecialist actors to defer to them..$^{93}$

Even the power of transnational capital is mediated through ideas. The tax treaties myth is an idea that supports an agenda in the interests of higher-income countries, although not, in general, one of "regressive redistribution" of tax revenue between states as posited by Dagan. Because the benefits accrue primarily to multinational firms themselves, rather than to the governments of the capitalexporting countries in which they reside, the narrative of this book is consistent with a business power perspective. ${ }^{94}$ To be sure, multinational firms possess significant instrumental and structural power. They lobby their home governments for tax treaties and make numerous inputs into transnational policy processes. Structural power is built into the tax treaties myth, since it leads policymakers in lower-income countries, who have not been lobbied, to fear that investment may be withheld or withdrawn without a treaty. For the most part, these mechanisms operate in a "quiet politics" environment unencumbered by public attention. ${ }^{95}$

Instrumental and structural power are most effective, however, when aligned with discursive power: the social construction of the tax treaties myth driving tax competition, and shared understandings within a transnational policy community whose members include multinationals' tax executives, as well as lawyers and accountants that service them. As some of the cases in this book will illustrate, the narrow interests of a transnational company in a certain country at a given time may be at odds with the long-term project of the international tax community. The fault line can run through the middle of business lobby groups. When discursive power pushes in a different direction than instrumental and structural power, the former tends to be more influential unless political pressure can be brought to bear on entrenched specialist bureaucrats.

\section{Past Legacies and Institutions}

This book is necessarily a historical narrative. Treaties are not negotiated in a vacuum but within an institutional framework built up over a century. It is clear from the evidence in this book that, as historical institutionalism argues, institutions built in the past condition states' options for cooperation in the present day. ${ }^{96}$ Already in the 1920s, northern countries in the League of Nations began to gain a first-mover advantage, deciding on the terms of cooperation in ways that privileged the interests of capital-rich countries over capital-poor countries. When representatives of lower-income countries were invited to join them, they questioned those decisions but were overruled. In the 1950s and 1960s, as the OECD became the institutional home of international tax cooperation, it built 
on the League of Nations work from the perspective of its capital-rich members. Ever since lower-income countries began to negotiate tax treaties from the late 1960s onward, they have had little option but to fall in line with the OECD, and the only alternatives to have gained traction have been compatible with (that is, based on) the OECD approach. ${ }^{97}$

As for formal rules and legal instruments, so also for the international tax community and its shared norms. The complex, decentralized, and imprecise design of international tax rules created the need for a large number of professionals to apply them, as well as the reliance on shared understandings of how to interpret those rules. ${ }^{98}$ To gain acceptance to that community, new entrants must comply with these norms, making it a challenging task to argue for any significant change from the inside. ${ }^{99}$

At the level of individual countries, past negotiations have an enduring impact on possibilities in the present. While a government may safely be able to say no to a treaty offered to it on bad terms, the calculation is different when such a treaty is already in effect, perhaps signed many decades ago. When terminating, overriding, or renegotiating an international agreement designed to offer stability to investors, there may be diplomatic and economic repercussions. Direct renegotiations do not start from a blank slate but from the agreement already concluded between two states. More importantly, past precedent shapes the conduct of new negotiations, and good negotiators will do their research. Countries can use this strategically, obtaining precedents from easier negotiations to bolster their positions in tougher ones to follow; conversely, today's negotiators will find their mistakes - and those made by their predecessors_- used against them.

\section{Evidence Base}

To build the argument throughout this book, I use evidence from interviews, participant observation in international meetings, and official documentation. In total, the book draws on seventy-five interviews with ninety-one stakeholders in the tax-treaty-making process, listed in the appendix. Of these stakeholders, most were or had been national civil servants involved in setting tax treaty policy, negotiating tax treaties (many were their country's lead negotiator), or administering tax treaties (the umbrella term "tax treaty officials" is used for all three types of civil servants). The sample also included twenty-seven individuals currently working in the private sector, primarily for business lobby groups and tax advisory firms, and eight international organization staff. ${ }^{100}$ The sample includes individuals from thirty different countries, including the case study countries. 
The interview sampling was a combination of convenience and purpose. Most of the interviews were conducted at meetings convened by the United Nations Committee of Experts on International Cooperation in Tax Matters ("UN Tax Committee"), but these were supplemented with some in-country interviews during incidental travel. In addition to the three contemporary case studiesCambodia, Vietnam, and Zambia-in-country interviews were conducted in Uganda, Kenya, Denmark, South Africa, and the United States. A multistakeholder focus group was also conducted at a tax conference in Nairobi in 2013, involving local businesses, tax advisers, revenue authority officials, and academics. The sampling strategy was designed to obtain a cross-section of countries by income and region. At the request of numerous interviewees, countries and names have been kept confidential.

Over thirty days of participant observation at international meetings, including hundreds of informal conversations, supplemented the interview data. These are also listed in the appendix. In particular, meetings of the UN Tax Committee are gatherings of dozens of tax treaty officials that last over several days. During formal proceedings, the twenty-five committee members speak in a personal capacity, while country observers speak on behalf of their country, and a small number of representatives from nongovernmental organizations (NGOs), the private sector, and academia also participate as observers. ${ }^{101}$ The meetings were an opportunity to observe the formal statements made by participants during the committee's deliberations, as well as the informal discussions during breaks and social functions. Comments made by committee members, however, cannot be attributed.

A degree of triangulation was also possible within the interview methodology. Triangulation techniques included speaking independently with negotiators who had experience across the table from each other, speaking with more than one official from the same country, and using field visits to focus on interviews with stakeholders who did not participate in international tax meetings, in particular in finance ministries and the private sector. It was also possible to triangulate between interview and observation data and other sources of information on the negotiating experience or practices of countries.

Written documentation was drawn from a number of different sources. Official statements were taken from written documents on government websites, parliamentary transcripts, and a number of archives, which also yielded internal discussions for historical sources. The UK National Archives, discussed in more detail in chapter 5, were an important source. Meeting agendas and minutes, as well as input documents, could be found in the online archives of the OECD/ OEEC and the United Nations, supplemented by a visit to the OECD archives and by copies of documents held in the British archives. In addition, the Public 
Library of US Diplomacy maintains a database of US diplomatic cables, including both a historical archive from the 1970s and leaked cables. ${ }^{102}$ Searches of the cables for "tax treaty" and "double taxation" yielded 232 results, mostly cables recording discussions between finance ministers or officials and US diplomats.

A final source of data for this book is a new data set of more than two thousand tax treaties signed by lower-income countries, which allows for a more powerful comparative analysis than has been conducted in any prior study. ${ }^{103}$ Each treaty is coded for twenty-eight points of variation, of which twenty-four reflect the protection for source taxing rights in the treaty. I constructed an index of overall source taxing rights, an average of these twenty-four provisions for each treaty. This gives a very broad assessment of each treaty, enabling a broad-brush comparative analysis between countries and over time. For example, there is a widening gap in the way that lower-income countries negotiate with each other, and the way that OECD member states negotiate with them. Figure 1.1 shows the negotiated content of tax treaties signed by lower-income countries, dividing their negotiating partners into two groups: OECD members and the G77 group of lower-income countries. Although there is some fluctuation over the long term, the gap has been widening over the past fifteen years.

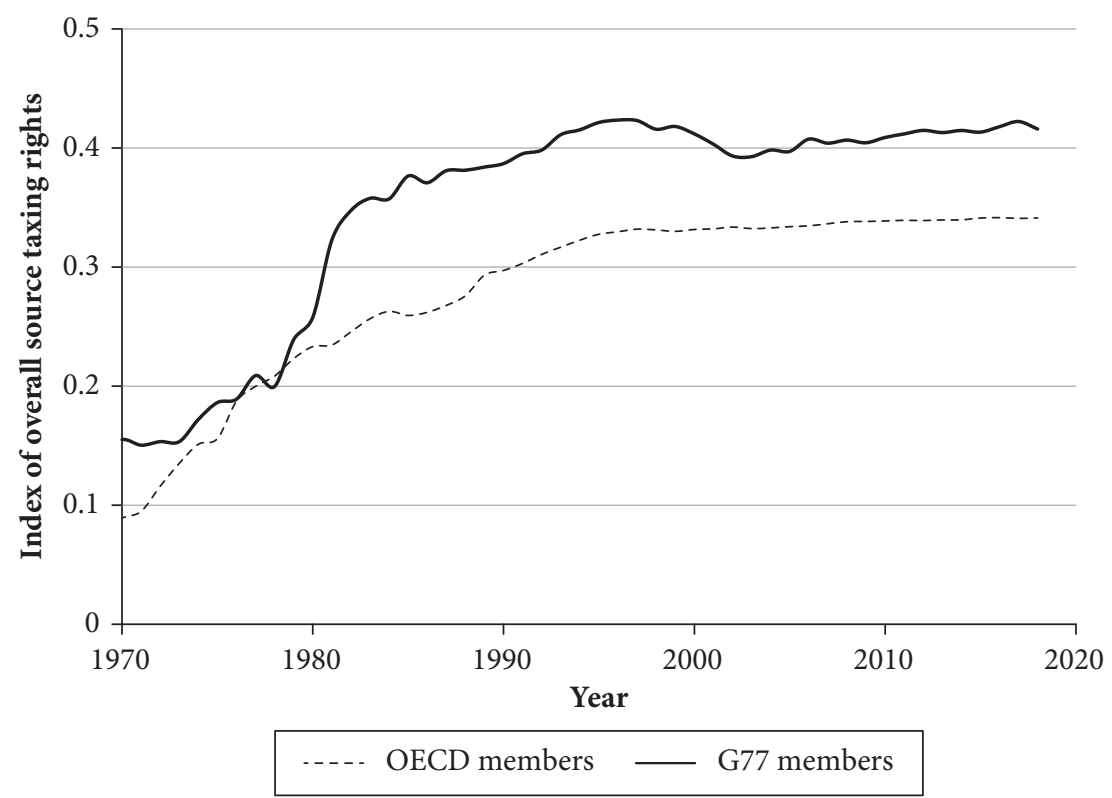

FIGURE 1.1. Overall source taxing rights in lower-income countries' tax treaties, cumulative, by treaty partner 


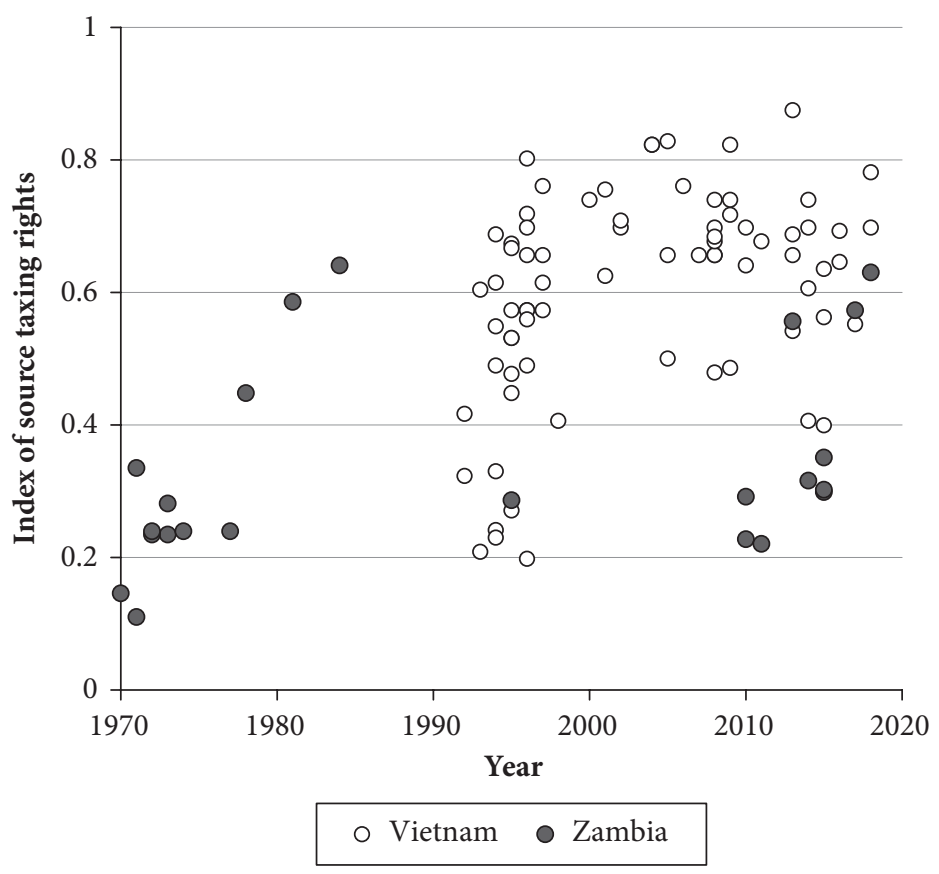

FIGURE 1.2. Overall source taxing rights in Vietnam's and Zambia's tax treaties Source: Hearson, "Tax Treaties Explorer."

Analysis using this data set allows me to go beyond previous quantitative research on tax treaties that has focused largely on withholding tax rates. Figure 1.2 illustrates this, showing how the index of overall source taxing rights can be used to study a country's negotiating history. It compares the treaties signed by Zambia and Vietnam. When Vietnam began negotiating, it signed some very residencebased treaties, subsequently concluding agreements that were more source-based. Zambia has been through the same process, twice: in the 1970s-80s and again in the 2010s.

\section{Outline}

The book is structured in two parts. Chapters 2-4 make the argument in general terms, beginning with chapter 2 , which gives a historical perspective on lowerincome countries' involvement in the international tax regime. It shows how, from the 1920s onward, higher-income countries dominated the development of the model tax treaties, first at the League of Nations and then at the OECD. While it 
is true that the design of institutions of cooperation reflected the preferences of the states for which the need for those institutions was most pressing, it is also clear that they used their first-mover advantage and economic strength to lock down the institutional design that now exhibits a bias in their favor. This pattern was not limited to the tax treaty regime and can be seen more broadly in the development of lower-income countries' tax systems, which have always been influenced by their position as rule takers and recipients of technical assistance.

Chapters 3 and 4 bring the analysis up to the present day, using interview, observation, and documentary evidence to characterize the mechanisms through which lower-income countries have been encouraged to conclude tax treaties. Chapter 3 focuses on actors who influence international tax policy but are not specialists, such as business executives, senior civil servants, and politicians. To do so, it emphasizes how such individuals act using bounded rationality, applying cognitive heuristics to process information. Interview and documentary evidence in this chapter show that decisions by lower-income countries to open tax treaty negotiations have at times been motivated by competition for inward investment, but that this is often hard to explain based on a model of purely rational legal and economic analysis of their likely impact. The chapter then turns the tables, demonstrating a strong evidence base that it is often higher-income countries that seek tax treaties with lower-income countries, in order to enhance the competitive position of their own multinationals.

The emphasis in chapter 4 is on the transnational tax policy community, whose members are at the heart of the international tax regime and of bilateral tax treaty negotiations. Through interviews and participant observation at international meetings, it demonstrates that community members share a set of ideas about tax treaties that differs from the ideas held by nonspecialist actors. They favor tax treaties not because of any immediate impact on investment flows but because they disseminate a set of standards that embody an acceptable and responsible way to tax multinational companies. The chapter argues that community influence can happen through "teaching" civil servants and through the influential position acquired by community members through their mastery of complex, interdisciplinary technical knowledge. Nonetheless, technical knowledge is a prerequisite for good negotiating outcomes.

The second half of the book consists of three case study chapters. The UK, discussed in chapter 5 , is an archetypal case, a country heavily implicated in the international tax regime and, during the 1970s, a prolific negotiator with lower-income countries. Archival evidence allows the detailed tracing of individual negotiations and substantiates the arguments of the first part of the book: negotiations were driven by the UK, to provide a competitive edge to its multinational investors; different conceptualizations of the benefits of treaties existed in the expert and 
nonexpert communities, leading to conflicting preferences, with the expert community controlling the negotiating process.

In chapter 6, archival evidence and field interviews allow for a comparison between Zambia's negotiations during the 1970s and the 2000s. In the earlier period of negotiations, negotiators lacked the technical capacity to understand the agreements they were signing, but believed tax treaties would attract investment. They were insulated from the tax costs at first by the government's large income from the mining sector. As a result, they signed away excessive amounts of taxing rights to higher-income countries. By the 2000s, learning from the international tax community gave officials a much greater understanding and a more precise set of objectives from treaty negotiations, including renegotiations, premised on community norms. They were unable to gain domestic political support for this negotiation program in an environment of falling mining revenues, until the 2011 election brought about an alignment of bureaucratic and political priorities.

Field interviews contrast Vietnam and Cambodia in chapter 7. The former is a hugely prolific tax treaty negotiator that, like Zambia, made some negotiating errors in its early days. Subsequently, it came to be known as a tenacious and expert negotiator, but the errors made in its earlier negotiations combined with an insistence on concluding as many treaties as possible continue to prove costly. Cambodia, in contrast, is a negative case. It came very late to tax treaty negotiation and then approached it cautiously. This was in part because of its limited state capacity, but mostly because a lack of corporate tax revenue increased the salience of the revenue costs in policymakers' minds, creating a strong skepticism toward tax treaties. The result has been a small number of well-negotiated treaties.

The book ends with a discussion, which draws on the preceding evidence as well as additional interviews and observation, of how the development of the tax treaty regime might encourage a rethinking of present-day challenges. If the North-South dimension is not surfaced as an important axis of conflict between states, the tools of tax cooperation will continue to deprive lower-income countries of revenue, even though they are being recast as weapons to help all states in the fight against tax avoidance and evasion. Lower-income countries should not continue to negotiate if they lack the capacity to do so with their eyes fully open, and must beware "capacity-building" efforts by states and international organizations with a vested interest in the present system. Expert knowledge about international tax is far from neutral. 